УДК 541.64

DOI: $10.33184 /$ bulletin-bsu-2020.4.11

\title{
STUDY ON THE DIFFUSION PROCESS IN PECTIN-MEDICINAL DRUG FILMS
}

\author{
(C) A. S. Shurshina*, E. I. Kulish, L. G. Kuzina, \\ V. M. Yanborisov, A. S. Titlova \\ Bashkir State University \\ 32 Zaki Validi, 450076 Ufa, Republic of Bashkortostan, Russia. \\ *Email: anzhela_murzagil@mail.ru
}

\begin{abstract}
The approaches to the targeted regulation of the sorption properties of drug polymer films and the rate of release of drug from the matrix are studied. Pectin was used as a polymer matrix, and chloramphenicol and dioxidine as medicinal substances. The experiments on water sorption by pectin films were carried out at $100 \%$ humidity under thermostatically controlled conditions $\left(T=25^{\circ} \mathrm{C}\right)$. The kinetics of drug release was studied by UV-spectroscopy. It was shown that the process of sorption of water vapor by a pectin film proceeds according to an anomalous mode, which may be associated with a delay in relaxation processes in glassy polymers. The introduction of drugs leads to a decrease in the rate of sorption, but does not affect the mode. In order to create prolonged dosage forms, a polymer film was modified by keeping calcium chloride in solution. Modification of the polymer film led to a change in the sorption mode from anomalous to pseudo-normal and to a decrease in the sorption rate in all studied cases. The found patterns of the sorption process were also reflected in the diffusion of drugs from the polymer matrix. As in the study of the sorption process, in the case of the release of drugs from the modified polymer film, the diffusion mode is pseudo-normal. An increase in the concentration of the drug ce and the modification time, as in the case of sorption of water vapor by films, is accompanied by a decrease in the rate of release of the drug substance from the polymer matrix.
\end{abstract}

Keywords: diffusion, drug delivery, pectin, modification.

\section{Introduction}

Nowadays medicinal polymer-based forms are of great interest for both therapy and pharmacy since they allow us to control the medicinal drug (MD) release from the polymeric matrix [1-7]. Such systems of MD delivery lower the level of side effects of medicaments and, in some cases, provide targeted delivery immediately to the disease sites [8].

By now, numerous researches have resulted in fundamental requirements which polymer medicinal forms should follow [9-11]. Among those are physicalchemical properties, biodegradability and biocompatibility, easiness to administer, softness and elasticity of the pharmaceutical form, etc. With respect to these requirements and taking into account the analysis of literature data, we find the delivery systems based on polysaccharides among the most promising [12-17]. Moreover, it is preferable to use natural compounds or their derivatives since they have extra curative properties. Thus, in some cases synergism - the increase in the pharmaceutical form activity - can be observed.

One of such polysaccharides, pectin, is a biocompatible, nontoxic, anionic natural polysaccharide extracted from cell walls of higher plants [18-21]. Due to the presence of hydroxyl, methoxy, and carboxy groups in a pectin molecule, it is possible to obtain a wide range of derivatives based on pectin, which allows us to modify such properties as solubility, hydrophobic nature, physical-chemical, diffusion, and biological features. The fact predetermines perspectives of its usage as a matrix to produce medicinal film forms [22-27].
The objectives of this article is to study the techniques aimed to control sorption properties of medicinal polymer films and the rate of medicinal drug release from the matrix.

\section{Experimental}

The study object is pectin (PC) of citrus origin produced by Sigma-Aldrich with the content of galacturonic acid exceeding 74.0\%. Chloramphenicol (Ch) and Dioxidine (DO) were used as medicinal drugs.

The films were obtained by flowing the PC solution onto a Petri dish surface glass. Bidistilled water was used as solvent. The PC concentration in the initial solution amounted to $2 \mathrm{~g} / \mathrm{dl}$. In case of producing drug-filled films, the MD dissolved in a small amount of water $(2 \mathrm{ml})$ was added while stirring to the PC solution immediately before films formation. The content of the medicinal drug in the film was $0.01 \mathrm{~mol} / \mathrm{mol}$ of PC.

Experiments on water sorption by PC films were carried out at $100 \%$ humidity under thermostated conditions $\left(T=25{ }^{\circ} \mathrm{C}\right)$. The relative quantity of water $\mathrm{m}_{\mathrm{t}}$ absorbed by the PC film sample by the moment of time $\mathrm{t}$ was determined using the gravimetric method by soaking the film samples in desiccator in water vapor for a definite time $t$ and the calculated as per the formula:

$$
m_{t}=\Delta m_{t} / \mathrm{m}_{0}
$$

where $m_{0}$ is the initial PC mass in the film, $\Delta m_{t}$ is the difference between the film mass at the moment of time $t$ and the initial PC mass in the film.

The experimental accuracy at $95 \%$ confidence interval and 5 replicates does not exceed $3 \%$. 
To study the kinetics of the medicinal drug release, the film sample was placed into a cell with distilled water. The MD released into the water phase was registered spectrophotometrically (using spectrophotometer Specord M-40 within the range of 220-350 nm) with the wavelength corresponding to the maximum of the medicinal drug absorption within the UV spectrum. The amount of the medicinal drug released from the film by the moment of time $t$ was estimated using the calibration function.

The experimental accuracy at $95 \%$ confidence interval and 5 replicates does not exceed $3 \%$.

\section{Results and discussion}

Fig. 1 (curve 1) presents the curve of the water vapor sorption by the PC film. The sorption curve's image is typical of unlimited swelling and the process of water vapor sorption results in the film dissolution.

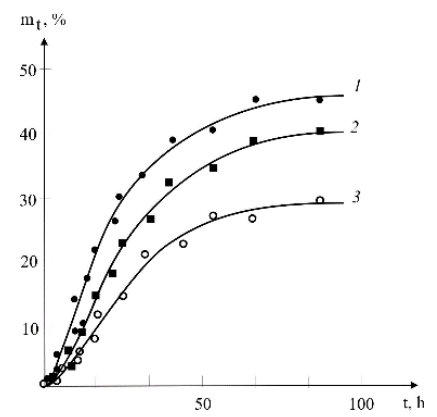

Fig 1. The kinetic curve of the water vapor sorption by films of PC (1), pectin-Ch (2), pectin-DO (3). Content of drug in the film is $1: 0.01 \mathrm{~mol} / \mathrm{mol}$ of pectin.

The analysis of the experimental data on the water vapor sorption by the PC film within the framework of the Ritger-Peppas equation shows that water vapor diffusion takes place by means of the anomalous mode $(n>0.5)$, which can occur due to the slowness of the relaxation processes in glasslike polymers such as PC.

When adding MD to the polymer film, the film remains soluble and the sorption curve does not change significantly and has the image typical of indefinitely swelling systems (Fig. 1, curve 2,3). At that, index $n$ characterizing the sorption mode decreases but the mechanism itself does not change (Table 1).
Besides, with the increase of the amount of the MD added the amount of the water absorbed and the rate of sorption decrease (Table 1).

To produce prolonged dosage forms modification of the polymer film via keeping in calcium chloride solution was performed. According to the literature data, cross-linking of polymer chains occurs as in the following scheme:

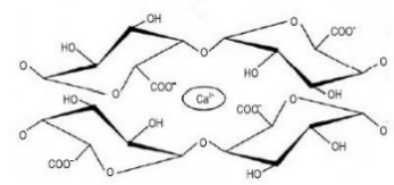

In all cases studied modification results in losing solubility by the films and, as a result, changes in the sorption curve pattern from unlimited to a limited one (Fig. 2).
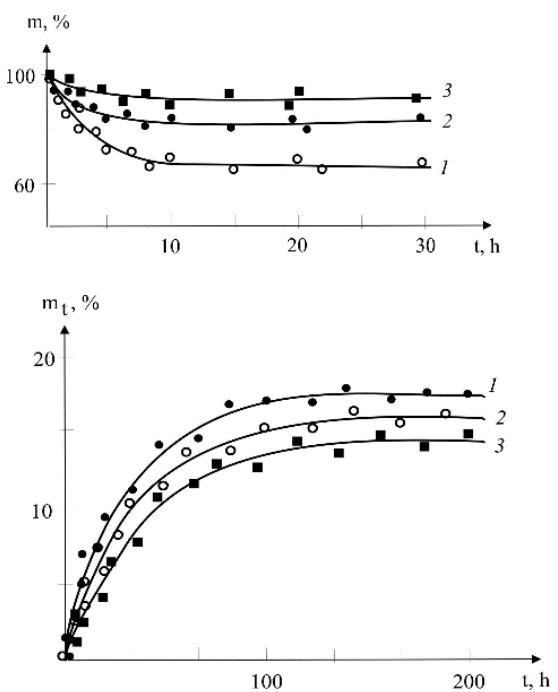

Fig. 2. Curves of the mass loss by the PC-LM film with the mole ratio 1:0.01 after modification by calcium chloride for 15 (1), 30 (2) and 120 (3) min (top). Kinetic curves of the water sorption by the PC-LM film with the mole ratio 1:0.01 after modification by calcium chloride for $15(1), 30(2)$ and 120 (3) $\min$ (bottom).

Parameters of water vapor sorption by the pectin films

\begin{tabular}{c|c|c|c|c|c}
\hline $\begin{array}{c}\text { Film } \\
\text { composition }\end{array}$ & $\begin{array}{c}\text { Drug content in the } \\
\text { film, mol/mol of PC }\end{array}$ & $m_{\infty}$ & $n$ & $D_{\mathrm{a}}{ }^{\mathrm{s}} \times 10^{11}, \mathrm{~cm}^{2} / \mathrm{sec}$ & $D_{\mathrm{b}}{ }^{\mathrm{s} \times 10^{11}, \mathrm{~cm}^{2} / \mathrm{sec}}$ \\
\hline PC & 0 & 0.46 & 0.61 & 12.2 & 28.3 \\
PC-Ch & 0.01 & 0.42 & 0.61 & 10.5 & 13.6 \\
PC-DO & 0.01 & 0.29 & 0.59 & 9.8 & 11.4
\end{tabular}

Table 2

Parameters of water vapor sorption by the pectin films after modification

\begin{tabular}{|c|c|c|c|c|c|c|}
\hline Film composition & $\begin{array}{l}\text { Drug content } \mathrm{n} \text { in } \\
\text { the film, } \\
\mathrm{mol} / \mathrm{mol} \text { of } \mathrm{PC}\end{array}$ & $\begin{array}{l}\text { Modification time, } \\
\text { min }\end{array}$ & $n$ & $m_{\infty}$ & $D_{\mathrm{a}}^{\mathrm{s}} \times 10^{11}, \mathrm{~cm}^{2} / \mathrm{sec}$ & $D_{\mathrm{b}}{ }^{\mathrm{s}} \times 10^{11}, \mathrm{~cm}^{2} / \mathrm{sec}$ \\
\hline \multirow{3}{*}{ PC-LM } & \multirow{3}{*}{0.01} & 15 & 0.41 & 0.167 & 2.7 & 1.9 \\
\hline & & 30 & 0.36 & 0.164 & 2.1 & 1.5 \\
\hline & & 120 & 0.34 & 0.147 & 1.4 & 1.1 \\
\hline \multirow{3}{*}{ PC-DO } & \multirow{3}{*}{0.01} & 15 & 0.42 & 0.172 & 3.4 & 2.6 \\
\hline & & 30 & 0.38 & 0.163 & 3.1 & 2.0 \\
\hline & & 120 & 0.38 & 0.149 & 2.5 & 1.8 \\
\hline
\end{tabular}


At that the increase in modification time results in the decrease in the amount of water absorbed and the rate of sorption (Fig. 2, Table 2).

Since there is an obvious interconnection between the processes of water sorption by polymer films and MD transport from them (as in the water medium a diffusion MD flow is directed from the film with the antibiotic towards the diffusion water flow moving into the polymer volume), the observed regularities of the sorption process are expected to have an impact on the characteristic features of the diffusion of medicinal drugs - antibiotics from the polymeric matrix.

Fig. 3 presents experimental curves of MD release from medicinal polymer films. When compared, the kinetic curves are apparently different, their pattern differ in cases of water-soluble and water-insoluble films the same way as in the study of the water sorption process. When the film is water-soluble, the process of the MD release is fast (a couple of hours) (Fig. 3, curve $1)$. The rate of the MD release in this case is determined by the ratio of the rates of MD diffusion from the film and the rate of the polymeric matrix dissolution. In the case when the film is water-insoluble, the MD diffusion is significantly slower and the kinetic curve reaches a sharply defined limit corresponding to the equilibrium yield of the MD (Fig. 3, curves 2-4).

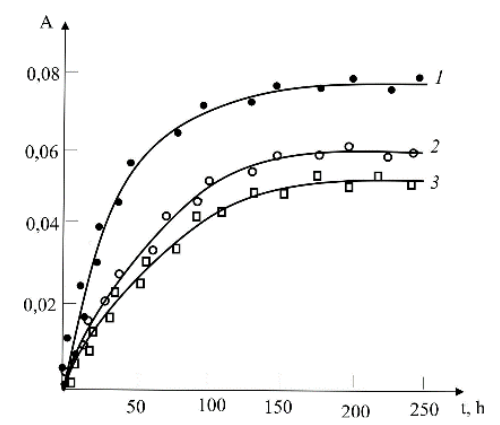

Fig 3. Kinetic curves of the medicinal drug release from PC-LM film systems in оптическая плотность - time coordinates with the time of modification 15 (1), 30 (2) and

120 (3) minutes. The mole ratio of PC-LM is 1:0.01.
The representation of data on the MD release in coordinates $\ln \left(\mathrm{G}_{\mathrm{s}} / G_{\infty}\right)-\ln t$ allows us to calculate parameter $\mathrm{m}$ characterizing, in this case, the mode of the diffusion process (Table 3). As could be expected, due to the fact that all the films under analysis are waterinsoluble the diffusion mode in all the cases studied is pseudonormal. The increase in the MD concentration and modification time, as well as in the case of water vapor sorption by the films, is accompanied by the complementary decrease of the parameter $\mathrm{m}$.

Thus, the regularities of the process of MD transport from the polymeric matrix are the same as those observed in the process of water vapor sorption by the films. Indexes $n$ and $m$ regularly change due to pectin transformation into the insoluble form via modification.

\section{Conclusions}

1. The process of water vapor sorption by pectin films has been found to comply with the anomalous diffusion mode.

2 . The process of water vapor sorption by pectin films has been showed to specify the regularities of the medicinal drug transport from the polymer film. In all the cases studied the index of power characterizing the mode of the medicinal drug transport from the polymer film changes symbasically with the change of the index of power in the Ritger-Peppas equation characterizing the mode of water transport into the polymer film.

3 . The values of sorption equilibrium and the indexes of power defining the diffusion modes decrease regularly with the increase in the time of the polymer matrix modification.

4. Convenient techniques to control the film transport properties including deliberate modification for obtaining restrictedly swelling films have been established. The techniques make it possible to change the rate and degree of the medicinal drug release from the polymeric matrix directly.

Table 3

Parameters of drug diffusion from pectin films

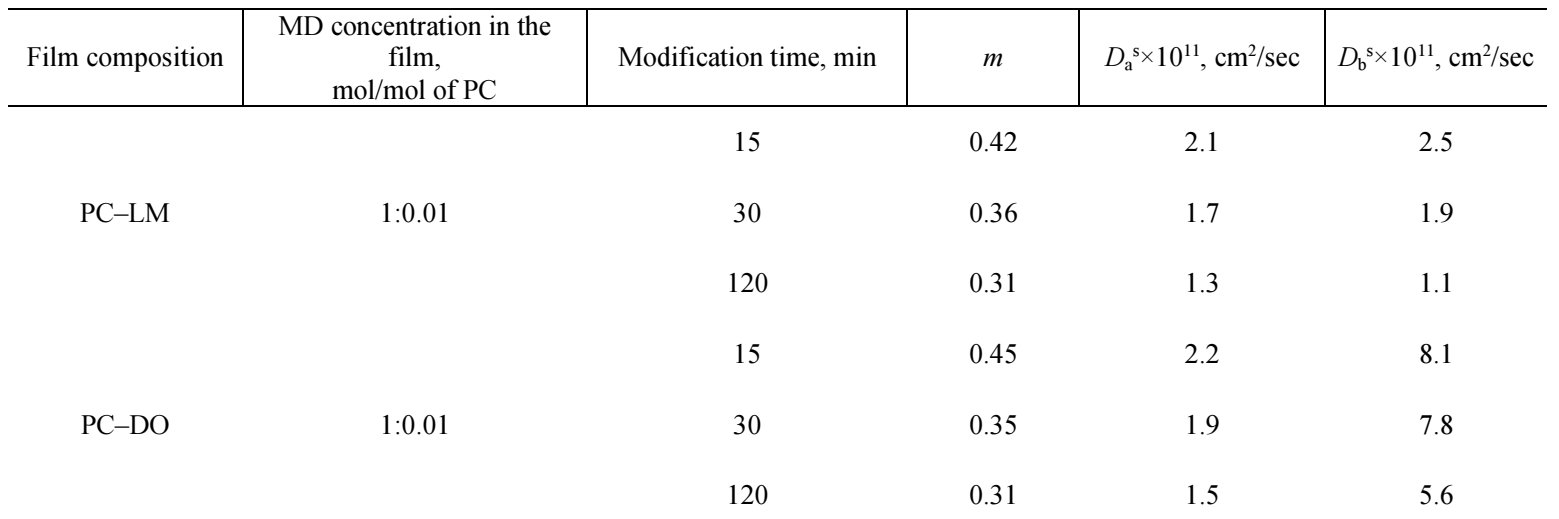




\section{References}

1. Shtil'man M. I. Biomaterialy - vazhneysheye napravleniye biomeditsinskikh tekhnologiy // Vestnik RGMU. 2016. No. 5. Pp. 4-15.

2. Nicolas J., Mura S., Brambilla D., Mackiewicz N., Couvreur P. Design, functionalization strategies and biomedical applications of targeted biodegradable/biocompatible polymerbased nanocarriers for drug delivery // Chem. Soc. Rev. 2013. Vol. 42. No. 3. Pp. 1147-1235.

3. Burg K. J., Porter S., Kellam J. F. Biomaterial developments for bone tissue engineering // Biomaterials. 2000. Vol. 21. No. 23. Pp. 2347-2359.

4. Biomaterials Science: an Introduction to Materials in Medicine / Ed. by B. Ratner, A. S. Hjffman, F. J. Schoen, J. E. Lemon. San Diego: Acad. Press, 2004. P. 709

5. Bajpai A. K., Shukla S. K., Bhanu S., Kankane S. Responsive polymers in controlled drug delivery // Progr.Polym.Sci. 2008. Vol. 33. No. 1. Pp. 1088-1118

6. Vilar G., Tulla-Puche J., Albericio F. Polymers and drug delivery systems // Current Drug Delivery. 2012. Vol. 9. No. 4. Pp. 367-394

7. Shaik M. R., Korsapati M., Panati D. Polymers in controlled drug delivery systems // Int.J.Pharm.Sci. 2012. Vol. 2. No. 4. Pp. 112-116.

8. Grigor'yeva M. V. Polimernyye sistemy s kontroliruyemym vysvobozhdeniyem biologicheski aktivnykh soyedineniy // $\mathrm{Bi}$ otekhnologiya. 2011. Vol. 4. No.2. Pp. 9-23.

9. Nazarenko G. I., Sugurova I. Yu., Glyantsev S. P. Rana. Bandage. Sick. M .: Medicine, 2002.

10. Qin Y. M. Advanced wound dressings // J. of the Textile Institute. 2001. Vol. 92. No. 1. Pp. 127-138.

11. Shapovalov S. G. Modern coatings in combustiology // PHARMindeks-Praktik. 2005. No. 8. Pp. 38-46.

12. Yusova A. A., Gusev I. V., Lipatova I. M. Svoystva gidrogeley na osnove smesey al'ginata natriya $\mathrm{s}$ drugimi polisakharidami prirodnogo proiskhozhdeniya // Khimiya rastitel'nogo syr'ya. 2014. No. 4. Pp. 59-66.

13. Kil'deyeva N. R., Kasatkina M. A., Mikhaylov S. N. Osobennosti polucheniya biosovmestimykh plenok na osnove khitozana, sshitogo dzhenipinom // Vse materialy. Entsiklopedicheskiy spravochnik. 2016. No. 4. Pp. 9-14.

14. Volkova M. V., Khasanshina Z. R., Popov S. V., Markov P. A. Gelevyye granuly iz pektina kallusa lupinus angustifolius predotvrashchayut prezhdevremennoye vysvobozhdeniye mesalazina // Biotekhnologiya. 2020. Vol. 36. No. 1. Pp. 53-60.

15. Selezneva I. I., Savintseva I. V., Vikhlyantseva Ye. F. i dr. Immobilizatsiya i dlitel'noye kul'tivirovaniye embrional'nykh stvolovykh kletok myshi $\mathrm{v}$ matrikse kollagen-khitozanovogo gelya // Kletochnyye tekhnologii v biologii i meditsine. 2006. No. 3. Pp. 135-140.

16. Galina A. R., Zidikhanova L. F., Shurshina A. S., Kulish Ye. I. O vozmozhnosti sozdaniya polimernoy formy applikatsionnoy anestezii prolongirovannogo deystviya na osnove natriyevoy soli karboksimetiltsellyulozy // Vestnik Bashkirskogo universiteta. 2019. Vol. 24. No. 2. Pp. 377-379.

17. Valiyev D. R., Bazunova M. V., Chernova V. V., Shurshina A. S., Kulish E. I. Biomedical materials based on polymercolloid dispersion of succinamide chitosan-sol of silver iodide // Inorganic Materials: Applied Research. 2018. Vol. 9. No. 5. Pp. 873-878.

18. Gordon A. Morris, Samil M. Kök, Stephen E. Harding \& Gary G. Adams. Polysaccharide drug delivery systems based on pectin and chitosan // Biotechnology and Genetic Engineering Reviews. 2013. Vol. 27. No. 1. Pp. 269-270.

19. Zidikhanova L. F., Kulish Ye. I., Chernova V. V., Shurshina A. S. Pektin-polimer prirodnogo proiskhozhdeniya // Doklady Bashkirskogo universiteta. 2018. Vol. 3. No. 6. Pp. 608-614.

20. Khatko Z. N. Innovatsionnyye pektinosoderzhashchiye kompozitsii na osnove vysokoochishchennogo sveklovichnogo pektina polifunktsional'nogo naznacheniya // Vestnik VGUIT. 2013. No. 6. Pp. 58-63.

21. Golubev V. N., Shelukhina N. P. Pektin: khimiya, tekhnologiya, primeneniye. M.: Izd. Akad. tekhnolog. nauk, 1995.

22. Wolfram D. L., Lippold B. C. Drug Release from Hydrocolloid Embeddings with High or Low Susceptibility to Hydrodynamic Stress // Pharm. Res. 1995. №12. P. 1781-1785.

23. Shelukhina N. P. Nauchnyye osnovy tekhnologii pektina. Frunze: Ilim, 1988.

24. Ofitserov Ye. N., Kostin V. I. Uglevody amaranta i ikh prakticheskoye ispol'zovaniye. Ul'yanovsk: OOO «Pechatnyy dvon», 2001.

25. Pat. 2206089 Rossiyskaya Federatsiya, MPK G01 N31/16. Sposob opredeleniya massovoy doli funktsional'nykh grupp poliuronidov / N.SH. Kaysheva (RF). №2001134132/04; zayavl. 13.12.2001; opubl. 10.06.2003.

26. Volkova M. V., Khasanshina Z. R., Popov S. V., Markov P. A. Gelevyye granuly iz pektina kallusa LUPINUS ANGUSTIFOLIUS predotvrashchayut prezhdevremennoye vysvobozhdeniye mesalazina // Biotekhnologiya. 2020. Vol. 36. No. 1. Pp. 53-60.

27. Kozhikhova K. V., Tolstykh D. A., Shulepov I. D., Kuznetsova D. O., Mironov M. A. Khimicheski sshityye mikrogeli, poluchennyye na osnove pektina, kak novyy sposob dostavki lokal'nykh anestetikov // Biofarmatsevticheskiy zhurnal. 2018. Vol. 10. No. 3. Pp. 41-50. 
DOI: 10.33184/bulletin-bsu-2020.4.11

\title{
ИЗУЧЕНИЕ ПРОЦЕССА ДИФФУЗИИ В ПЛЕНКАХ ПЕКТИН- ЛЕКАРСТВЕННОЕ ВЕЩЕСТВО
}

\section{(C) А. С. Шуршина*, Е. И. Кулиш, Л. Г. Кузина,} В. М. Янборисов, А. С. Титлова

Баикирский государственный университет Россия, Республика Башкортостан, 450076 г. Уфа, улицуа Заки Валиди, 32.

*Email: anzhela_murzagil@mail.ru

\begin{abstract}
Изучены подходы к целенаправленному регулированию сорбционных свойств лекарственных полимерных пленок и скорости высвобождения лекарственных веществ из матрицы. Было показано, что процесс сорбции паров воды пленкой пектина проходит по аномальному режиму. Введение лекарственных веществ приводит к уменьшению скорости сорбции, но не сказывается на режиме процесса. С целью создания пролонгированных лекарственных форм проводилась модификация полимерной пленки путем выдерживания в растворе хлорида кальция. Модификация полимерной пленки привела к смене режима сорбции с аномального на псевдонормальный и к уменьшению скорости сорбции во всех изученных случаях. Найденные закономерности процесса сорбции нашли свое отражение и в особенностях диффузии лекарственных препаратов - антибиотиков из полимерной матрицы.
\end{abstract}

Ключевые слова: диффузия, доставка лекарственных средств, пектин, модификация.

Поступила в редакичию 29.05.2020 2. 